\title{
HOW FAR SHALL THE JUSTICE AND RIGHTS OF THE PARTICULAR CAUSE PREVAIL OVER A STRICT APPLICATION OF ESTABLISHED RULES OF LAW ?*
}

It has grown to be the fashion in these modern days, both by tongue and by pen, to criticise public men so openly, whether in the executive, legislative or judicial branches of government, that we may properly inquire whether, in this respect at least, liberty has not degenerated into a license that may in time undermine true liberty itself. Unrestrained license may lead freedom and liberty into the maelstrom of anarchy, and, if not checked, might make it possible for us to believe that the day may come when the real liberties of man will be better preserved by a form of government so centralized and strong that our forefathers would have ranked it as tyrannical, yet far less injurious to mankind than a government, vaunted to be of the people, by the people and for the people, but in reality so enervated by permissive license as practically to forbid to its citizens that which we term our inalienable rights, personal security, personal liberty and the enjoyment of private property. I need not particularize; every thinking man knows the situation. Against such possibilities the foremost defenders should be the priests of the law, the members of the legal profession, and they the very last to assist the consummation of such an evil. It may be said that this sounds the alarm too loudly, but not so to this body when we remember that criticism of judicial authority by the coadjutor of the Bench-for none other is the Bar-has far more effect upon the public than that which flows from the pen of the editor, the pencil of the cartoonist, or the rantings of the demagogue, the socialist or the modern labor agitator.

We do well, therefore, to stop for a moment to consider the question: What is the Bench, and what is the Bar, and in what manner are they jointly the guardians of the temple of justice?

* This article formed part of an address delivered by the author as President of the Pennsylvania Bar Association, at the annual convention, June 29, 1903 . 
"Sir," said Horace Binney, "the Supreme Court is the august representative of the wisdom and justice and conscience of the whole people in the exposition of their constitution and laws; the peaceful and venerable arbitrator between the citizens of all questions touching the extent and sway of constitutional power, the great moral substitute for force in controversies between the people, the States and the Union." These words, spoken of the highest and most powerful court the world has ever known, are proportionately true of all those who wear the spotless ermine on every appellate or nisi prizis bench in this or any other Commonwealth. Of the honored position to which every lawyer, true to his profession, is entitled, the eulogium of Lord Coke will suffice: "For thy comfort and encouragement cast thine eyes upon the sages of the law that have been before thee, and never shalt thou find any that hath excelled in the knowledge of the laws but hath drawn from the fountains of that divine knowledge, honesty, gravity and integrity; and, by the goodness of God, hath obtained a greater blessing and ornament than any other profession to their family and posterity. It is an undoubted truth that the just shall flourish as the palm tree and spread abroad as the cedars of Lebanon. Hitherto, I never saw any man of loose and lawless life attain to any sound and perfect knowledge of the law; and, on the other side, I never saw any man of excellent judgment in the laws but was withal (being taught by such a master) honest, faithful and virtuous. Wherefore, a great lawyer never dies improlis aut intestatus, and his posterity continues to flourish to distant generations."

The Bench and the Bar are joined in upholding the fabric of the law by securing the administration of that justice of which Webster said: "It is the greatest interest of man on earth. It is the ligament which holds civilized nations together. Wherever her temple stands, and as long as it is duly honored, there is a foundation for social security, general happiness and the improvement and progress of our race. And, whoever labors on this edifice with usefulness and distinction, whoever clears its foundations, strengthens its pillars, adorns its entablatures, or contributes to raise its august dome still higher in the skies, connects himself in name and fame and character with that which is, and must be, as durable as the frame of human society."

Our profession is a great Brotherhood to which belong the judges, the advocates and the lawgivers of all the ages, and when 
we cast our eyes back along the world's history there appears in ail its glory the might, the majesty, the power of the legal profession as manifested by this exalted fraternity.

Moses, writing under divine inspiration, gave Israel a system of laws which will endure with time itself, combining in his person the brotherhood of the law, for that, as his Pentateuch shows, he was the inspired lawgiver, the upright judge, and the advocate for his people even amid the thunderings of Sinai; leaving for ali men of every age a code which contains the basic germs of the civil law, of our common law and of the statutes of every modern nation.

In the eighth century before Christ, Lycurgus rescued Sparta from anarchy by a constitution securing a form of government superior to many. in the old world to-day; a constitution only excelled by our own, and by which, indeed, ours was in part inspired. "And though," as has been well said, "the constitution of Sparta was framed twenty-seven hundred years ago, for a region no larger than an ordinary county in an American State-a mere speck on the map of the globe-yet the light of that great legal instrument has never gone out, but has continued to shine across the vast and turbulent centuries, like the imperishable beacon of a great lighthouse, streaming far out over the ocean as a warning, a guide and a hope."

Aesthetic and cultured Greece fell early in the struggle of nations, but her civilization, manifested through her code of laws and the constitutions written by Lycurgus and Solon, so impressed itself upon the jurisprudence of her conqueror as to preserve her fame to all ages. All-conquering Rome mastered a world in domain far more extensive than that over which flies our flag, and in population nearly double that of our Union, yet was preserved as a Republic for nearly seven hundred years more by her brotherhood of lawgivers and lawmakers than by her legions; and now that she lies in the dust there rises from her ruins, higher than her art and her literature, the towering majesty of her jurisprudence, her codes, her laws and her system of government. Of the period of the dawn of Christianity the name of Cicero, the great leader of the Roman Bar, and among the most exalted of all the lawyers the world has ever known, is inscribed higher than those of her historians, Tacitus and Livy, and of her poets, Virgil, Juvenal and Horace. Five hundred years later, when her fate seemed imminent, she was revived almost to her pristine strength by the renowned Tustinian, an emperor whose victories in battle restored the ancient 
borders of his country and whose patronage of the arts decorated the Imperial City much more lavishly than had any of his predecessors; yet all that is as naught to-day compared with the immortal Code Justinian, the foundation, and largely the body of the civil law which governs modern Europe, and from whose Pandects and Institutes even the fountains of our common law have ever been re-enforced.

Of all England's kings the historian gives the place of honor to Alfred; but he was not Alfred the Great because he drove the Norseman and the Dane from Albion's shores, nor alone for that he ruled wisely and well, but chiefly because he was the greatest lawgiver of his age, himself compiling a code of laws, writing valuable legal treatises, and placing the administration of justice upon a stable foundation by his selection of able and honest judges and the revival and firm establishment. if not by the origin of the jury system, not materially differing from the form in which we know it to-day. The swords that wrung Magna Charta from King John at Runnymede would have accomplished nothing enduring had not that famed instrument been penned by a lawyer's hand. Shaven priest as he was, Stephen Lagngton wrote with the pen of a giant of our brotherhood when he indited the Great Charter of Liberties. Who but a lawyer of the highest rank in our profession could have written: "No freeman shall be seized, or imprisoned, or dispossessed, or outlawed, or in any way destroyed; nor will we condemn him, nor will we commit him to prison, except by the legal judgment of his peers, or by the law of the land"? And no words could better define the proper administration of justice and the conduct of the judiciary, whether in a court presided over by the ancient feudal -king or by the modern elected judge, than those which Langton wrote into that charter: "To none will we sell, to none will we deny, to none will we delay justice." These are the basic principles of liberty, controlled by law, which with the other sentences of that immortal document extend to every department of jurisprudence, covering the correlative rights and duties of crown and subject; of all the domestic relations, of debtor and creditor, of principal and surety, of decedents' estates, of courts of superior and inferior jurisdiction, of taxation, of military duty, and of the law merchant.

With Magna Charta stand the Petition of Rights, the Bill of Rights, the writ of Habeas Corpus and our Constitution as 'monuments of the brotherhood to which, judge and advocate alike. we 
yield our homage; a fraternity resplendent with the names of Cicero and Justinian, of Coke and Bacon, of Mansfield and Erskine, of Marshall and Webster, of Gibson and Binney, of Sharswood and Black, and of all the host of those who have gone before, leaving to us this noble inheritance to be passed on to those who come after us untarnished and undiminished in splendor.

Do we realize that in addition to the fealty mutually due the members of this brotherhood of our profession-the fide ity of Bar to Bench, the courtesy of judge to advocate-as patriotic citizens, we owe a debt of gratitude to the courts for that whicl they have done to ensure our liberties and maintain our government? For it is a truth everyone must admit that all of the glory of the establishment and preservation of our Union of States is not due alone to our honored Presidents, our gallant leaders of army and navy, or to the statesmen in our halls of Congress. The principles enunciated by our courts on the vital questions of constitutional and civil liberty are shining lights in our national progress. In the infant days of the Republic a mere stroke of the pen might have overthrown our fabric, while the utterances of the judicial branch of our government had a large share in cementing the Union. Not surrounded by glories of martial array, nor amid the plaudits of Congress, unnoticed by the press and not specially marked by the historian, but patiently, and in the seclusion of chambers, the destiny of our nation was forged by the pens of the great jurists who adorned our Federal Bench. Beside our nation's George Washington we must place our brotherhood's John Marshall, and enroll the names of Story and of Cushing, of Livingston and of Chase, high in our halls of fame. When we study our national history closely and analytically we cannot fail to discover that the judicial department of our government it was that stayed and maintained our tottering columns of state as they were swaying toward ruin, and with judicial deliverance of sound wisdom and statesmanlike strength cemented our structure to withstand the storms and revolutions of any age.

I have reviewed, though but feebly, the glorious history of our noble brotherhood of judges and lawyers, that I might more strongly accentuate the duty of always evincing the highest honor and respect ever due from Bar to Bench not only because of professional pride in -preserving the prestige of our ancient and honorable fraternity of the law, but that in so doing we sustain liberty itself, uphold justice and maintain the due and proper administration of 
the law; for it must be admitted that the permanency of our institutions depends solely upon the majesty of the law, which will be preserved only so long as the Bar maintains such a proper respect for the Bench as will thereby command full obedience to its decrees from all the world. De Tocqueville, writing in 1835 , seemed to be distrustful of the permanency of our institutions, but considered that the conservatism of the American Bar was a guarantee of their stability, and that our Bench and Bar constituted our best aristocracy, being founded upon intellectuality and morality. Excepting that in some respects our brotherhood has lowered its prestige by laxity in guarding its portals-a fault more evident in Bar than in Bench-and by a growth of commercialism in some quarters, which, if not checked, will destroy the highest and best ethics of our profession, it is certain that if the distinguished author of "Democracy in America" could view us from the same standpoint seventy years later, he would find that our institutions are still safe-guarded by the legal profession, in that the citadel of justice is manned by the sworn servants of the law, and that so long as they are faithful to their duty her walls will ever protect the institutions which have combined to make ours the foremost nation of the day or of history.

The stream can rise no higher than its source, hence the Bar makes the Bench what it is, and when the profession, true to its great trust, raises its voice in the selection of the judiciary with such vigor that all men, even the modern politician, must obey, and having placed its choice in the highest position man can hold-because he who judges others exercises one of the highest attributes of the Almighty himself - continues to support the Bench in the exercise of its duties, justice will be properly administered, the law upheld, and thereby government maintained. So, likewise, if any one chosen to this great office becomes unfaithful to his trust, no matter how high may be his station, the duty of the profession is equally mandatory, and as a judge that man must cease to exist.

With all deference, I venture to suggest the qualities of the ideal judge as the one who listens patiently, weighs justly and judges wisely; not always bound by

"The codeless myriad of precedent, That wilderness of single instances,"

irrespective of modern progress and changed conditions, yet unwilling to abandon the rule of stare decisis even by modifications 
which "eat out the heart of the rule," in order that particular facts may prevail, where the former decision has become a rule of property by which men have bought and sold, contracts have been prepared, estates passed, domestic relations determined and the profession practiced for many years; yet, not bound by bands of iron so rigid and unbending that in order to uphold a stern rule an injustice will be done so great that the conscience of man will be shocked. In short, the judge who knows both how to measure what is right and just by the law, as well as to measure the law by what is just and right. Again, the ideal judge, whether at nisi prius or on appeal, is not truly appraised by popularity, for it was well said in ancient days that "a popular judge is a deformed thing, and plaudits are fitter for players than for magistrates." And with this sage advice may go the words of another ancient master who would warn his judges thus:

"Draw thy learning out of thine books, not out of thine head."

"Mix well the freedom of thine own opinion with due reference to the opinion of thy fellows."

"Be a light to jurors to open their eyes, not a guide to lead them by their noses."

"Affect not the opinion of pregnancy and expedition by an impatient and catchy hearing of the counsellors at the bar."

After all is said, may we not sum up the qualities of an ideal judge in the answer of one of England's greatest premiers to a request for a judicial appointment? "If your friend is a gentleman I will give him this judgeship; if he knows a little law, then so much the better." That eminent statesman must have borne in mind the fact that England's greatest jurist, the immortal Mansfield, excepting America's Marshall and Pennsylvania's Gibson without a peer, had never been ranked while at the bar as its leader or as a brilliant advocate, while, on the other hand, the wonderfully gifted and versatile Lord Bacon and the illustrious Erskine were sad failures when elevated to the Bench. Of Bacon, his biographer said: "No man ever sat in Westminster Hall with a truer judicial understanding; no one ever more thoroughly understood the duties of a judge, while his professional acquirements and experiences were sufficient to dispose of all the variety of business which came before him." As an illustration of his ability we need only recall that the chancery system of practice in Pennsylvania is founded upon and almost entirely drawn from his famous "Orders." Yet he descended to the lowest servility in personally soliciting the 
woolsack from James I., and so disgraced his great office that he was dismissed for receiving from suitors bribes to the amount of many thousands of pounds. Of him the poet said:

"If parts allure thee, think how Bacon shined, The wisest, brightest, meanest of mankind."

It cannot be denied that Erskine was one of the two greatest advocates the world has ever known-Webster alone equalling him in oratory while surpassing him in profundity. Called to the bar as a mere youth he made his debut in Rex $v$. Baillie with such success that he was immediately overwhelmed with retainers, and for twenty-seven years led the English Bar, unequalled by any who there preceded or followed him; but the deliverance of the Great Seal to him was but the equivalent of the termination of his glory, for in the six months he held the office of Lord Chancellor he delivered no opinions of importance and resigned the woolsack conscious of his inability to fill that exalted office, and, following the custom of his country that forbids the Bar to the retired judge, soon sank into comparative obscurity, his position in Parliament being but mediocre.

No judge could wish for a higher eulogium than that pronounced of Mansfield: "When he goeth up to the judgment seat he taketh care to put on righteousness as a glorious robe, and to render his tribunal a fit emblem of that eternal throne of which justice and judgment are the habitation." So always for every great judge there is emblazoned on his shield the motto of Chevalier Bayard: "Sans peur et sans reproche," to which in these modern days may well be added "et sans approche," proclaiming to the world that impartial justice will be meted out to all men alike, indifferent to the frowns of power, the temptations of corruption and the subtle artifices of practiced ingenuity.

It is a common fashion to measure men of the day with those of other times, whether statesmen, soldiers or jurists, to the disparagement of the modern, as if the present with all its progress in things material must have retrograded in the moral and mental strength of its leaders in the science of statesmanship, of war, or of jurisprudence. Yet it is undoubtedly true that those whom we revere as the legal giants of other times were not without criticism from their contemporaries, and that their judgments may have been objected to almost as freely as are those of to-day. The novelist, Charles Lever, puts this very cleverly in his Martins of Cro' Martin, where he gives us this anecdote of the Irish Exchequer: "The 
Chief Baron had overruled every objection made by Counselior Repton, and at last declared he wouldn't hear any more citations whatsoever. 'But I have a stronger case still,' insisted the Counsellor. 'I'll not hear it, sir,' retorted the Court. 'It is in Crewe \& Fust, Term Reports, page I438.' 'I don't care where it is, sir.' 'In a charge delivered by Lord Eldon.' 'Oh, let us hear my Lord Eldon,' said Plumridge, the puisne Judge, who was rather ashamed of the Chief Baron's severity; 'let us hear what my Lord Eldon may have said.' 'Here it is, my Lord,' said the Counsellor, opening the volume and laying his hand on the page; 'Crewe and Fust's Pleas of the Crown, page 1438 , my Lord Elden says, "I may here observe that the Courts of Law in Ireland are generally wrong; the Court of Exchequer is always wrong." '"

After all, is not this criticism of Bench by Bar one of the marks of the advocate of which the active lawyer cannot entirely free himself? The battle is over and lost, but the warrior must keep his sword is hand and lance in rest, and is unable until after its more vivid memories are past to review his cause calmly, when, if he can do so dispassionately and judicially, he must admit that much of his earlier criticism of the decision was unwarranted. Let any lawyer honestly review the causes he has lost in the appellate courts, applying judicial interpretation and divorcing himself entirely from all partisanship, and he will find that but very few were unjustly or improperly decided. He will discover that there was another standpoint, not without merit, and while he vigorously maintained his own, and at the time believed it should have been adopted, he cannot now say on his honor and conscience that the decision was without reason or justice. The sum of the matter is that so long as our judges hold the bench without reproach and without approach the fountains of justice will remain undefiled, and while in the hour of defeat we may not feel that justice has been done our client, we cannot conscientiously say when we have viewed the question impartially, that the decision would not have been ours had we been charged with its adjudication.

This criticism of judicial decision by the unsuccessful advocate is of but little moment in comparison with an arraignment of the Bench of Pennsylvania upon an indictment charging them with a fault alleged to be destructive of the rights of suitors and of the proper administration of the law. It has been said by a leader of the Bar of that Commonwealth, a lawyer of profound wisdom and the highest legal attainments, that the modern tendency of the 
courts is to adjudicate causes by their particular equities, rather than by "the knowne certaintie of the law;" to be influenced by facts conducive to judgments based upon what would seem to the courts just and right in the particular case, rather than to be controlled by the strict application of settled legal principles. This method of administering law, he tells us, is more Oriental than Anglo-Saxon, increasing commercialism at the Bar by encouraging litigation, and, if not restrained, bringing us to a condition where no man will know what his rights are; fostering a disrespect for and -discontent against all law, and resulting in the loss of public confidence in the courts to be shown by the refusal to continue for long terms our faithful judges. Coming from so high a source, we do well to stop to consider this important matter, and, if we are likely to suffer the pains and penalties suggested, to join in the alarm.

First of all: What is "the knowne certaintie of the law?" It may be questioned if there ever was or will be any certainty in this science; its very nature denies it that quality. It was Coke who gave this label to the law, but we may well doubt if he found its substance, and if his age, far less complex than ours and existing under conditions much more simple, could not determine this "knowne certaintie of the law," how much less may we? $\mathrm{He}$ tells us that "ffifteen books of treatises and as many volumes of reports" then completed a legal library. If uncertainty in adjudications prevailed then, what of our times when we live under conditions of wonderful development and variety, and Coke's thirty law books have multiplied into as many thousands? Lord Coke may well stand for an example of lawyers of his class; learned, profound, honest and wise, and who would measure what is right, just and fair between man and man by the rigid rules of law, rather than to measure the law by the rules of justice and right. In short, with them whatever is custom is necessarily right, and that which is not in accordance with custom is utterly wrong. Indeed, is not that a mental characteristic of our English cousins to-day in many matters of manners and modes of life? It was Coke who said that law was "the very embodiment of common sense," a saying of his that may be ranked with the one first quoted, yet the didactic mould of his mental processes led him to absurdities, and plain common sense has often declined to accept his legal principles. Perhaps the most glaring example of arrant nonsense and gross injustice suryiving from the days of judges like Coke is the infamous Rule in Shelly's case, by which we in this enlightened age 
are compelled to practice, and which we have time and again known to have robbed the deserving, and utterly destroyed the testator's intent, because, forsooth, a rule of law must be upheld and the judges forbidden to apply equitable principles to the facts in a particular case in order that justice may be done and the right prevail. I know of no better illustration of the "knowne certaintie of the law" than this, often resulting, as Judge Black said of the New York Code, "in law on the rampage and justice bedevilled."

Of the adherence to settled rules of law, it is admitted by all hands that certain legal principles have been established-although not all uniformly in every court of last resort-and to those principles additions are constantly being made, and so far as they may be conscientiously applied, must prevail; but it may well be asked where is the legal principle that can stand the strain of time unless it be bottomed and fastened upon natural justice?- that which we call equity, because in this sense it is indeed "the correction of that wherein the law by reason of its universality is deficient." Rules of law may be firmly declared, and to them we must bend the knee of obedience, but unless they have for their foundation a justice which appeals to man's conscience, they are as unstable as the shifting sands of the sea. And herein is the very warp and woof of the question at issue.

The maintenance of a "knowne certaintie of the law" is practically an impossibility, and against that saying of Coke may be set up a still older one, now gone into a proverb: "The glorious uncertainty of the law." Upon many questions these uncertainties are fundamental, arising from the very nature of the law, and are not to be overcome. The differences in human reasoning, as well as in standpoint and environment, necessarily produce these uncertainties, whether in construction or in administration. A divine law was given man, yet that law receives a different construction from Christian, Jew and Moslem, each acknowledging its divine inspiration and accepting the same words. Divinity founded a church on earth and endowed it with constitution and laws, yet it remained truly catholic, or universal, for but a comparatively brief period, dividing into Eastern and Western churches, chiefly on the construction of but a single idea and the use of but one word, so unimportant in the scheme of salvation that it may well be doubted if any but the theologian or those versed in its history know what is ecclesiastically meant by the filioque. The great Western Church, never entirely agreed-exampled by the struggles between the 
Anglo-Saxon people and the Roman See-finally split at the Reformation on questions of construction and administration, and those who went their own ways again divided, always on similar questions, until now the divisions of Christianity. are almost countless. Can we expect human law to be more of a "knowne certaintie" than that which has been revealed from heaven?

Aside from various modes of reasoning whereby different interpretations are arrived at even under similar conditions, there has .ever been and always must be an evolution in the law, a progress in jurisprudence, as there is in forms of government, human thought, modes of life, manners and customs, and in the arts and sciences through new discoveries and inventions. That which may have been a well settled and accepted principle of law at one stage of human progress would not be tolerated for one moment in these modern days; the earlier legal treatises are full of such principles, they are not merely obsolete, they are positively denied by advanced thought and by the results of experience. The law cannot stand still any more than can mankind cease to progress; as one goes forward so must the other, and as human conditions improve and develop, so, of necessity, must jurisprudence advance. There are certain principles of natural justice which are as immutable as the heavens and can never be changed; they have come to us from antiquity, they will last so long as man walks the earth; and believing in a just Judge before whom we must all appear, will continue throughout eternity. These principles no man can change, no court alter, no judge destroy; they are certain and will so remain. Other principles, not necessarily founded upon natural justice, but, rather, artificial rules made for a particular time, for special conditions, or to serve a purpose later found to be but temporary or transient, must and will change, and it is at this point we may meet the precise question under discussion.

The foremost and chief principle of all law, and one which cannot be changed, is that justice is to be done, that that which is right and just shall alone be decreed. A law that is not just, or wlich in its application works an injustice, will not and cannot survive. It may be hoary with age, it may be written in every law bock, but when it comes in contact with circumstances where its application would do that which the conscience of man declares to be unjust it must give way. Such a law may survive for a time, even for a long time, but its doom is sealed; if the courts refuse relief from its oppression, the people will sweep it away, and with 
it, perhaps, much else that should not be lost. The Rule in Shelly's case is the best, or, more properly, the worst illustration. It is a part of "the knowne certaintie of the law" which has been so vigorously upheld; other States have wiped off that excrescence from their jurisprudence, even our conservative Commonwealth will not tolerate it much longer. To the judge who evades that unjust rule in order that justice may be done under the particular circumstances of the case, no criticism is due, and his decree is a progression, not a retrogression in jurisprudence. That which is true of this ancient and time-dishonored rule is proportionately true of many other established principles of law.

Rules of law must be promulgated, and, so long as they do no wrong, must be upheld, but let us not forget the ringing words of Magna Charta, the Great Charter of our liberties, from which not one jot or title should be lost: "To none will we sell, to none will we deny, to none will we delay justice." The barons did not demand, nor did the learned Chancellor, Stephen Langton, indite a demand for a "known certaintie of the law," but by point of lance and edge of sword they dragged from King John that which he could certainly, albeit none the less unwillingly, grant, namely, justice. If law in its application and administration is not to be controlled by justice, then, indeed, are we "stretched upon a procrustean bed" and a "barbed wire fence pens us in the field," and if we stir on the one or run against the other the sharp prongs and barbs of the law will pierce us to the quick and soon bring us to "death's doings."

If we are to have rules of law hard and fast, and are to bind them so tightly around our judges as to compel them to be followed by the strictest construction, without conscience and without heart, then will our courts become mere machines of learning to force the facts of every cause within those "procrustean" rules, irrespective of the destruction of natural right, and regardless of that justice which will then meaninglessly define their official titles, but which by law and by conscience they have been sworn to uphold; all, forsooth, that we may have the "knowne certaintie of the law," and that the advocates having applied its measuring stick to their clients' causes may be assured that it may likewise be the means of adjudication by the Bench, irrespective of the wrongs done to others. Imagine for a moment what this would mean to the ignorant and unwary. The shrewd, the learned, the well advised, the unscrupulous, could eat up the careless, the ignorant, the trusting, and no matter how just may be the "particular circumstances of the cause" 
and how much may conscience be shocked by the judgment, it must be rendered if thereby "the knowne certaintie" is assured. Then, indeed, would all our previous conditions and beliefs be reversed, and justice would become uncertain and law certain. It might then be that the assurance of justice could only be had on that side of the temple where the jury are judges both of the law and of the facts, and where with them established precedent or custom must yield to whatever they may guess to be right.

It has been suggested that if the tendency of the couris to adjudge causes by the particular equities of the case be continued, public distrust may follow, and the electors may refuse to continue for long terms the otherwise faithful judges. Rather let us look at the converse of the proposition and if the public come to believe that the courts are bound by precedent rather than by justice, by rule rather than by what is just and right, that decisions are made which shock the conscience and are contrary to that which men believe to be natural justice, we may see the time when the elective franchise will compel a statute that the jury shall be the judges of the law in all cases, whether civil or criminal, and where then, we may well ask, will there be any certainty either of law or justice?

It is true that there are cases to be found in the reports where the courts of last resort have departed from established precedent in order that justice might be done under the'particular circumstances of the case, and I am glad to be of those who maintain that such a course is conducive to the proper administration of jurisprudence. A careful consideration of that class of cases will disclose, I am firmly convinced, that their adjudication was based upon facts that permitted justice to be done only by departing from rules of law, which, if followed, would have been to permit an injustice so gross as to shock the conscience.

An illustration of this, though no doubt better could be found, is Carpenter v. Life Insurance Co., I6I $\mathrm{Pa} .9$, and the same case 174 $\mathrm{Pa}$. 639. At trial the defendant had successfully relied upon stare decisis, a long line of authority in Pennsylvania, as well as in the Federal and other courts, that an insurable interest, clearly defined, was essential to a recovery upon a life policy; adjudications founded upon a rule of public policy that to permit such contracts would be to put a premium on human life, and that a wagering policy was but conducive to a desire for the death of the insured, a desire which in at least one reported case (Mutual Life Ins. Co. v. Armstrong, II7 U. S. 578) had been followed by its 
felonious accomplishment. In the case cited as an illustration it was admitted on the trial that "the plaintiff was not a creditor of the irsured, nor a relative, nor connected by ties of blood or marriage, but only a friend of the insured ;" an admission of fact which under the established rule of "the knowne certaintie of the law" put the plaintiff out of court, and the defendant was accordingly dismissed with the premium in its pockets and the policy unpaid. If on appeal the settled rule of law had been applied, and natural justice and meritorious right had been disregarded by a refusal to consider the particular facts of the case, the judgment must have been affirmed. But it was not affirmed because of those particular facts which were that the plaintiff, a poor young woman, had been befriended and educated by the insured and given an opportunity to earn her livelihood by a respectable occupation. That she might have some support after his death, and before her technical education was completed, he gave her this policy on his life, assigning it to her out and out. Every reason for the application of the rule was wanting, because in fact her interest was much greater in the preservation than in the destruction of the life of the insured; but, measured by the rule of law, she was without legal redress. Be it said to the credit of the Supreme Court of Pennsylvania that the judgment was reversed, based upon the ground that the insured was to the plaintiff in loco parentis, although in point of fact she had been of full age for a number of years. We might quarrel with the reason for the reversal, but not honestly with any judgment which gave her the money to which she was rightfully entitled.

We may here rest the further discussion of this question, though it will continue to be raised so long as our profession includes those who, like their prototype, the inflexible Coke, maintain that rules of law once established must ever be strictly followed, irrespective of the wrong done in the particular cause, judging solely from the head without influence from the heart, and denying the elasticity of the law to adapt itself to man's changed conditions, as well as to his environment and progress. But while there is the other school in our profession, modern though it may be, yet largely in the majority, we may rest assured that the law will be measured by what is right and just, compelling its severity to yield to justice as the basic principle of all law. The duty of the Bar is to demand purity in the Bench, and then to uphold it as part of the great brotherhood of the law to which, judge and advocate alike, we are solemnly sworn, yet none the less is it the duty of the Bar to hold the Bench to the strict observance of that obligation of Magna 
Charta, forever binding upon every judge: "To none will we sell, to none will we deny, to none will we delay justice."

When shall come that great day bringing us all before a Judge whose justice man can but feebly imitate, we will not ask for that "certaintie of the law" under which we must all stand condemned, but rather for that justice and mercy whereby alone we may hope for an eternal reward, relying upon an assurance of salvation, "because $\mathrm{He}$ hath appointed a day in the which $\mathrm{He}$ will judge the world in righteousness."

C. La Rue Munson. 